https://doi.org/10.46813/2022-137-046

\title{
APPLICATION IN A LINEAR PROTON ACCELERATOR OF A NON-VAPORABLE Zr(86)-Al(14) GETTER LOCATED INSIDE THE CHAMBER OF A PLASMA-ION PROTON INJECTOR FOR ITS ADDITIONAL PUMPING
}

\author{
A.M. Aksonova, V.V. Belicov, S.A. Vdovin, P.L. Makhnenko, M.M. Pylypenko, A.P. Podolyak, \\ E.I. Ponomarchuk, O.P. Svynarenko, V.I. Skibin \\ National Science Center "Kharkov Institute of Physics and Technology”, Kharkiv, Ukraine \\ E-mail: anna.aksynova@gmail.com
}

The rates of pumping hydrogen and nitrogen by the non-evaporable $\mathrm{Zr}(86)-\mathrm{Al}(14)$ getter located inside the chamber of a plasma-ion proton injector are investigated. The measurements at the temperature range $473 \ldots 1300 \mathrm{~K}$ and pressures from 13 to $10^{-3} \mathrm{~Pa}$ were carried out. The highest pumping rates of hydrogen $((283 \pm 15) 1 / \mathrm{s})$ and nitrogen $((133 \pm 15) \mathrm{l} / \mathrm{s})$ achieved at the temperature range $525 \ldots .575 \mathrm{~K}$ and pressure from 13 to $10^{-3} \mathrm{~Pa}$ has been established. It is shown that the proposed non-evaporated getter $\mathrm{Zr}(86)-\mathrm{Al}(14)$ provided the required operating pressure in the chamber of the plasma-ion injector of the linear proton accelerator and the minimum concentration of hydrogen, nitrogen, and other residual gases.

\section{PACS: 81.05.-t, 07.30.-t}

\section{INTRODUCTION}

The use in the linear proton accelerator [1] of the non-evaporated $\operatorname{Zr}(86)-\mathrm{Al}(14)$ getter, located in the chamber of the plasma-ion proton injector for its additional pumping out, can significantly improve the injector performance. And this makes it possible to expand the use of the accelerator both in the fields of scientific research and applied applications. It should be noted that these are one of the areas that determine the progress of modern development of science and technology $[2,3]$. The proton injector is that part of the accelerator design that largely determines the quality of the accelerator operation and, as a consequence, the efficiency of its use. For the normal operation of a linear proton accelerator, it is necessary that the system of its vacuum pumping would provide the required pressure in the vacuum case of the accelerator, the proton injector and the channel where the protons are accelerated before hitting the target. In this case, the largest gas load during the operating accelerator takes place in the chamber of the proton injector, which requires its additional pumping out. For this purpose, during the research, a non-evaporated $\mathrm{Zr}(86)-\mathrm{Al}(14)$ getter was used, which made it possible to maintain in the injector chamber both the required operating pressure and the composition of residual gases with the minimum necessary concentration of hydrogen and other impurities in them: hydrocarbons, water vapor, their fragments, noble gases ...

Analysis of literature data [1] and preliminary studies carried out in this work showed that the placement of the $\mathrm{Zr}(86)-\mathrm{Al}(14)$ getter inside the injector chamber for its additional pumping has advantages over all other methods used for pumping hydrogen in a vacuum volume with high hydrogen gas load. Therefore, the proposed method for placing this getter will improve the performance of the injector. Thus, by changing the temperature of the getter, it is possible to set the required pressure of residual gases, including hydrogen, in the injector chamber in a more controlled manner.

The non-evaporated $\mathrm{Zr}(86)-\mathrm{Al}(14)$ getter used in this study, also known as St (101), is capable, under certain conditions, of absorbing irreversibly reactive gases: $\mathrm{O}_{2}$, $\mathrm{N}_{2}, \mathrm{CO}, \mathrm{CO}_{2}$, water vapor, hydrocarbons $-\mathrm{CH}_{4}, \mathrm{C}_{2} \mathrm{H}_{2}$, $\mathrm{C}_{2} \mathrm{H}_{4}$, their fragments: $\mathrm{CH}, \mathrm{CH}_{2}, \mathrm{CH}_{3}$, and reversibly hydrogen and its isotopes.

The properties of the getter proposed for use in this work, its operating characteristics, and application features are described, for example, in [4-6].

Over time, during the operation of the getter, its sorbing surface is passivated and the rate of gas sorption decreases to an unacceptable level. Therefore, it is necessary to set both the time until the next activation of the getter surface and the possible time of its use for operation in the accelerator. And this can only be done experimentally. Therefore, this information is of interest, since make it possible to determine the most acceptable operating conditions of the injector in the accelerator, which will make it possible to improve the performance of the accelerator and, thereby, the efficiency of its use.

The purpose of this work is to determine the optimal operating parameters of the injector chamber - its working pressure, to achieve the minimum required residual pressure of hydrogen, nitrogen and other gases, to determine the operating time of the proposed getter before the next next activation of the surface and the total time of its operation.

\section{RESEARCH TECHNIQUE}

To study the rates of pumping out hydrogen and nitrogen from the injector chamber with a getter placed inside it, the "constant volume" method was used [7].

In Fig. 1 shows a schematic diagram of pumping out the injector chamber (a) and a view of its internal structure (b). Chamber 1 , in which the getter 2 is located, is pumped out by three fore-vacuum pumps of the BNR-2 type 3 and two vapor-oil diffusion pumps of the VM-5 type 4 . With the help of five vacuum valves 
5, the pressure required to perform a specific experiment is created in it. Hydrogen is injected into the injector chamber through valve 6 , and the pressure in it is measured by three gauge transducers 7 .

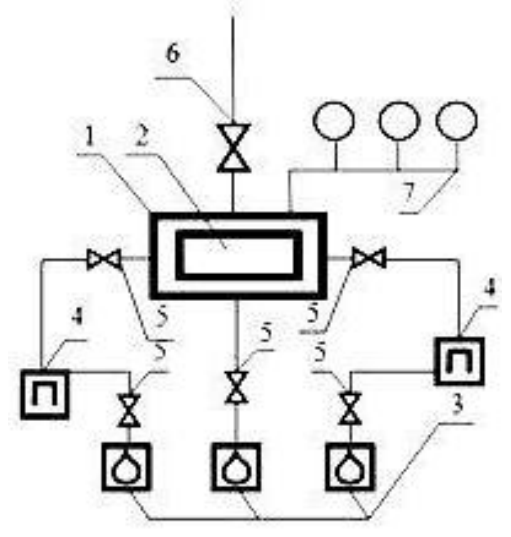

$a$

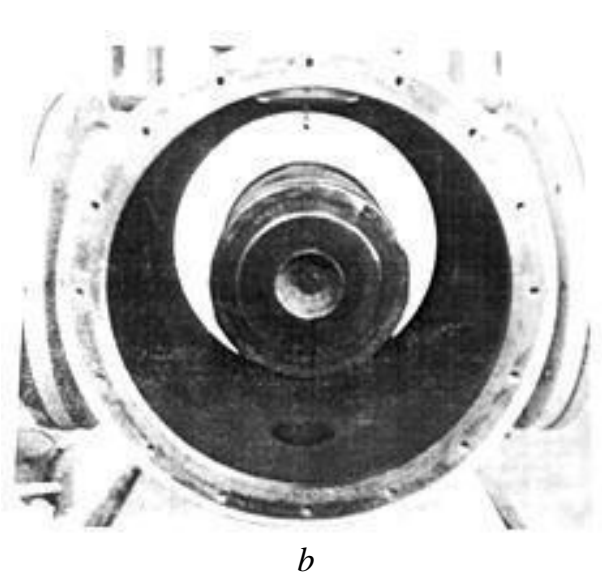

Fig. 1. Schematic diagram of pumping the injector chamber: 1 -injector chamber; 2 - getter;

3 - backing pumps; 4 - oil-vapor diffusion pump;

5 -vacuum valve; 6 - hydrogen inlet valve into the injector chamber; 7 - gauge converters (a). View of the

internal structure of the injector chamber $(b)$

When conducting research in the pressure range: $13.33 \ldots 0.13$ and $0.13 \ldots 10^{-5} \mathrm{~Pa}$, converters LT-2 and LM-2 with a VIT-3 vacuum gauge were used, in the range $133.3 \ldots 10^{-3} \mathrm{~Pa}$ - converter PM-10-2. The measurement of the partial pressures of the residual gases in the injector chamber in the range of $1.33 \ldots 10^{-8} \mathrm{~Pa}$ was carried out by a PMI-27 manometric transducer with a VI-14 vacuum gauge.

The view of the internal structure of the injector chamber is shown in Fig. 1,b.

The injector chamber has a design typical for injectors of known proton accelerators. All parts of the injector, their location and dimensions are designed and manufactured in such a way as to maximally meet the requirements for the operation of the accelerator.

\section{SAMPLES FOR RESEARCH}

Particles of a getter extracted from crushed ingots obtained by fusion of iodide zirconium and aluminum $(99.998 \%)$ were used as samples for research. The fusion was carried out by the method of arc melting with a non-consumable tungsten electrode. The resulting ingots were crushed mechanically and particles of $\sim 0.02 \ldots 0.04 \mathrm{~cm}$ in size were separated from the crushed mass. In the injector chamber, they were located on a tape made of X18H10T stainless steel placed on insulators.

In Fig. 2 shows a part of this tape with getter particles located on it.

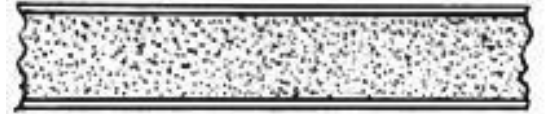

$a$

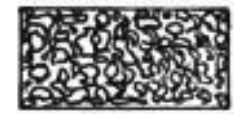

b
Fig. 2. Part of the tape with getter particles located on it (top view): a-decreased by 4 times; $b$-increased by 10 times

The getter is distinguished by high operational reliability, its operation is stable for a long time (more than $500 \mathrm{~h}$ ). It does not crumble with the release of solid particles into the injector chamber when it is heated to temperatures above $1200 \mathrm{~K}$, which significantly reduces the risk of electrical breakdowns in it.

The getter temperature in the injector chamber was measured with a chromel-alumel thermocouple, which was located on the surface of the tape under the layer of getter particles.

\section{RESULTS AND DISCUSSION}

In this work, to obtain protons, plasma is used, formed in the injector chamber with the help of highfrequency fields. This method of producing protons can initiate a high-voltage breakdown in the chamber with the further establishment of a gas discharge with selfsustaining electron-ion avalanches that violate its dielectric strength. In this case, a malfunction of the accelerator, damage to its individual units and, as a consequence, unsuitability for further operation is possible. In this case, a malfunction of the accelerator, damage to its individual units and, as a consequence, unsuitability for further operation is possible.

When choosing the working pressure in the injector chamber, it is necessary to take into account that as the pressure decreases, the mean free path of electrons increases and they acquire more energy in the electric field. However, in this case, the number of collisions with atoms of residual gases, including with hydrogen atoms, decreases, which leads to a decrease in the number of protons formed [3].

One of the main requirements for the composition of residual gases in the injector chamber is the minimum concentration of hydrogen in it. It is impossible to estimate with sufficient accuracy its amount that passed ionization and then hit the accelerator target as protons.

These protons have different velocities and therefore, when they are decelerated on a stationary target, the temperature control of which is not provided for in its design, results with a wide range of values are obtained, which complicates their correct interpretation. Ultimately, this leads to a decrease in the efficiency of the accelerator application.

The results of measurements of the rates of pumping out hydrogen $\left(S_{H}\right)$ and nitrogen $\left(S_{N}\right)$, obtained in this work with the getter located inside the injector chamber, 
are presented in the Table and in Figs. 3 and 4; in the Table at a pressure in the chamber of $10^{-3} \mathrm{~Pa}$, and in Figs. 3 and $4-$ at a pressure in it of $10^{-2}$ and $\sim 10^{-3} \mathrm{~Pa}$, respectively.

All measurements were carried out for the case when the injector chamber is included in the general vacuum pumping system of the accelerator, i.e. valve 6 shown in Fig. 1,a, is open.

Results of measurements of the pumping rate of hydrogen $\left(S_{H}\right)$ and nitrogen $\left(S_{N}\right)$ at a pressure in the injector chamber of $10^{-3} \mathrm{~Pa}$

\begin{tabular}{|l|c|c|c|c|c|c|c|}
\hline No & $T, \mathrm{~K}$ & $\begin{array}{c}S_{H}, \\
1 / \mathrm{s}\end{array}$ & $\begin{array}{c}S_{N}, \\
1 / \mathrm{s}\end{array}$ & No & $\begin{array}{c}T, \\
\mathrm{~K}\end{array}$ & $\begin{array}{c}S_{H}, \\
1 / \mathrm{s}\end{array}$ & $\begin{array}{c}S_{N}, \\
1 / \mathrm{s}\end{array}$ \\
\hline 1 & 473 & 155.3 & 73.0 & 9 & 593 & 193.6 & 91.0 \\
\hline 2 & 483 & 236.0 & 111.0 & 10 & 603 & 193.6 & 91.0 \\
\hline 3 & 503 & 236.0 & 111.0 & 11 & 613 & 193.6 & 91.0 \\
\hline 4 & 513 & 236.0 & 111.0 & 12 & 623 & 155.3 & 73.0 \\
\hline 5 & 523 & 283.0 & 133.0 & 13 & 633 & 55.3 & 26.0 \\
\hline 6 & 553 & 283.0 & 133.0 & 14 & 643 & 55.3 & 26.0 \\
\hline 7 & 573 & 283.0 & 133.0 & 15 & 653 & 55.3 & 26.0 \\
\hline 8 & 583 & 236.0 & 111.0 & 16 & 673 & 0 & 0 \\
\hline
\end{tabular}

The rates of pumping out hydrogen and nitrogen in the injector chamber were obtained for the temperature range $473 \ldots 673 \mathrm{~K}$ in the case when the sorbing surface of the getter is not strongly passivated and its ability to absorb residual gases remains at a rate close to the maximum for this temperature range.

From the results presented in the table, it is necessary to note a decrease in $S_{H}$ and $S_{N}$ with an increase in temperature from $\sim 550$ to $675 \mathrm{~K}$, where they are no longer registered by the method used in this work.

Fig. 3 shows the temperature dependences of $S_{H}$ and $S_{N}$ at a pressure in the injector chamber of $10^{-2} \mathrm{~Pa}$ for the case when a getter is placed in it.

Fig. 3 shows that the rates of hydrogen absorption are relatively low in the entire range of the studied temperatures. So, for hydrogen it does not exceed $\sim 60 \mathrm{l} / \mathrm{s}$, nitrogen $\sim 30 \mathrm{l} / \mathrm{s}$. In this case, the change in $S_{H}$ and $S_{N}$ with a temperature in the range of $475 \ldots 675 \mathrm{~K}$ is $\sim 10 \mathrm{l} / \mathrm{s}$ for $S_{H}$ and $\sim 3 \mathrm{l} / \mathrm{s}$ for $S_{N}$. Such relatively small ranges of changes in the temperature dependences of $S_{H}$ and $S_{N}$ significantly limit the possibility of finding the optimal operating mode of the injector at a pressure in its chamber of $10^{-2} \mathrm{~Pa}$. Therefore, this pressure is not acceptable for injector operation.

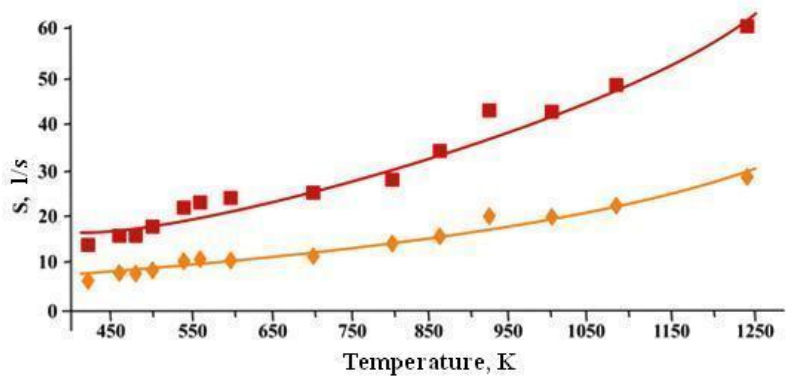

Fig. 3. Temperature dependences of $S_{H}(\square)$ and $S_{N}(\diamond)$ at a pressure in the injector chamber of $10^{-2} \mathrm{~Pa}$
Fig. 4 shows that the lines describing the temperature dependences of $S_{H}$ and $S_{N}$ have maxima located in the temperature range $525 \ldots 575 \mathrm{~K}$, and they converge to the point where the temperature is $675 \mathrm{~K}$.

As the pressure in the injector chamber decreases to $10^{-3} \mathrm{~Pa}$, the shape of the curves describing the temperature dependences of $S_{H}$ and $S_{N}$ changes significantly (see Fig. 4).

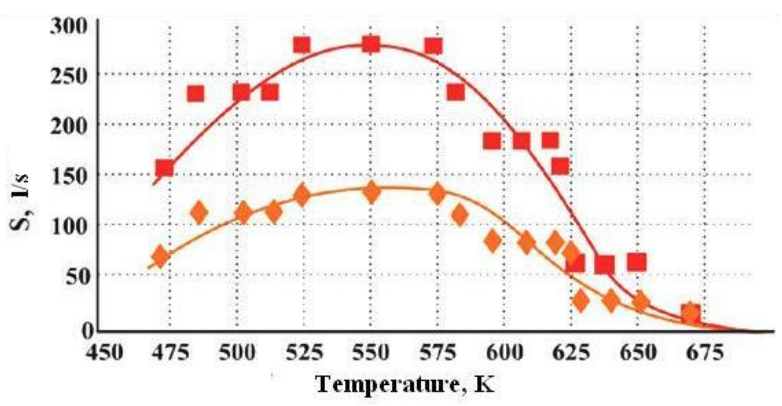

Fig. 4. Temperature dependences of $S_{H}(\square)$ and $S_{N}(\diamond)$ at a pressure in the injector chamber of $10^{-3} \mathrm{~Pa}$

Comparison of the temperature dependences of $\mathrm{S}_{\mathrm{H}}$ and $S_{\mathrm{N}}$ at pressures of $10^{-2}$ and $10^{-3} \mathrm{~Pa}$ shows that for the entire temperature range at which the measurements were carried out, the values obtained at a pressure in the injector chamber of $10^{-3} \mathrm{~Pa}$ are always higher than at $10^{-2} \mathrm{~Pa}$. In the temperature range $525 \ldots 575 \mathrm{~K}$, these rates have the highest values and decrease with increasing temperature, even at $\sim 625 \mathrm{~K}$ are quite sufficient to control and select the optimal injector operation mode with acceptable accuracy.

Shown in Fig. 5, the curve showing the temperature dependence of the specific rate of hydrogen pumping by the non-evaporated getter $\mathrm{Zr}(86)-\mathrm{Al}(14)$ at a pressure in the injector chamber of $10^{-3} \mathrm{~Pa}$ is quite informative.

It can be seen from its analysis that the selected getter provides the required pressure in the injector chamber in the temperature range: $475 \ldots 675$ K. Starting from a temperature of $550 \mathrm{~K}$, the dependence of the specific rate of hydrogen pumping decreases, and at a temperature of $\sim 605 \mathrm{~K}$ it has an inflection point and then approaches zero, to the point corresponding to $675 \mathrm{~K}$, where the absorption of hydrogen is no longer recorded by the method used in this work. The data presented in Fig. 5 also confirm that the method of using the getter - placing it inside the injector chamber in the form of particles of a certain size and using the activation of its surface to bring it into the state to sorb gases - is quite justified. Thus, the facts presented above allow us to assert that one of the main requirements for the getter proposed for use is fulfilled - the provision of the required operating pressure in the injector chamber during accelerator operation. These facts also make it possible to better understand and use the technological capabilities of the proposed getter.

In Fig. 6 shows a histogram of partial pressures in the injector chamber at a pressure of $10^{-3} \mathrm{~Pa}$ for the case when its additional pumping inside the injector is carried out by a non-evaporated getter. 


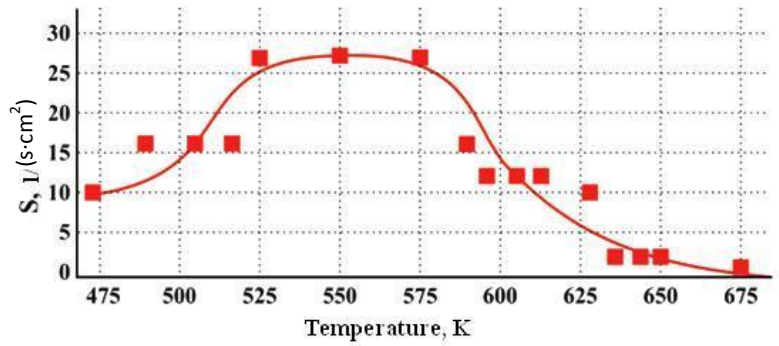

Fig. 5. Temperature dependence of the specific rate of hydrogen pumping by a non-evaporated $\mathrm{Zr}(86)-\mathrm{Al}(14)$ getter from the injector chamber at a pressure of $10^{-3} \mathrm{~Pa}$ (taking into account the edge temperature effect $l / d$, where lis the length of the tape covered with getter particles, and d is its width)

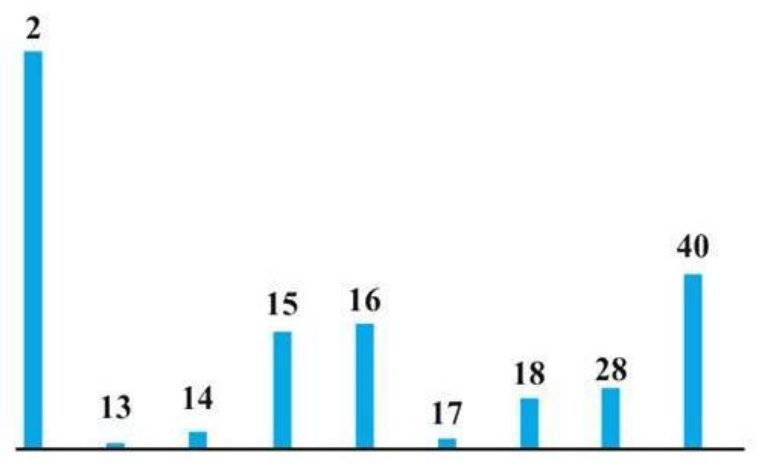

Mass number

Fig. 6. Histogram of the composition of residual gases in the injector chamber at a pressure of $10^{-3} \mathrm{~Pa}$

The measurement results presented in the histogram were obtained before the outgassing of the walls of the injector chamber and the proton acceleration channel.

Comparison of the measurement results shown in Fig. 6, with similar ones, but only for the case when the additional pumping of the injector chamber is carried out by electric discharge pumps of the NORD-250 type, showed that the use of a non-evaporated getter has a significant advantage - a lower concentration of hydrogen and other impurities in the chamber, determined in the composition of residual gases at a pressure in her $10^{-3} \mathrm{~Pa}$.

All measurements were carried out before degassing the walls of the chamber and the proton acceleration channel. The results shown in Fig. 6 - partial pressures of residual gases (or, more correctly, the mass numbers corresponding to them) are characteristic of vacuum volumes, the inner surfaces of which have not been subjected to any special treatment [8]. The highest concentrations are found for hydrogen and argon. Other mass numbers presented on the histogram refer to hydrocarbons $\left(\mathrm{CH}_{4}, \mathrm{C}_{2} \mathrm{H}_{4}\right)$, water vapor, and their fragments.

When analyzing the results presented on the histogram, it is necessary to take into account that the techniques used to study the gaseous medium strongly depend on many factors: the instruments used, their distance to the vacuum volumes where measurements are taken, the diameter of the supply pipes, the vacuum fittings used - vacuum taps, valves, connecting sleeves, angles, vacuum seals, etc. Therefore, these techniques may somewhat fail to reflect the real picture, which takes place in a vacuum volume, but not even detect gases with a high sorption bond energy, for example, water vapor or oxygen. Instead of these components of the gaseous environment, the content of hydrogen and inert gases will be overestimated [8]. Therefore, when explaining and using the results presented in the histogram, they should be considered only as qualitative estimates.

However, these estimates are sufficient to draw a conclusion about the compliance of the composition of the residual gases in the injector chamber with the requirements imposed on them - an acceptable minimum content of hydrogen and other impurities characteristic of these operating conditions of the accelerator.

It is practically impossible to quantify the composition of residual gases presented in the histogram. For a pressure of $10^{-3} \mathrm{~Pa}$, at which the measurements were carried out, this composition can differ significantly depending on the history of the inner surface of the injector and the state of it at the time of measurements. And this state is determined by the superposition of many, poorly controlled, simultaneously occurring processes on its surface [9].

Comparison of all the results obtained in this study showed that the non-evaporated $\operatorname{Zr}(86)-\mathrm{Al}(14)$ getter, proposed for additional pumping out of the injector chamber, can provide both the required operating pressure and an acceptable composition of residual gases in it, i.e. meet the requirements for a getter when used in a linear proton accelerator.

The operation of this accelerator with improved injector performance for more than $500 \mathrm{~h}$ is a sufficient justification for the feasibility of using the proposed getter.

An important factor when using a non-evaporated getter by the method proposed in this work is also a decrease in power consumption during operation of the accelerator. So, its savings when replacing previously used electric discharge pumps is $14.8 \mathrm{~kW} \cdot \mathrm{h}$ for one working day lasting eight hours for one electric discharge pump of the NORD-250 type.

\section{CONCLUSIONS}

1. The use of a non-evaporated $\mathrm{Zr}(86)-\mathrm{Al}(14)$ getter for additional pumping of hydrogen from the injector chamber of a linear proton accelerator has significant advantages over all known previously applied methods.

2. The pumping rates of the hydrogen $((283 \pm 15) 1 / s)$ and nitrogen $((133 \pm 15) \mathrm{l} / \mathrm{s})$ for additional pumping out of the chamber of the plasma-ion proton injector obtained in this work provide the required operating pressure $\left(10^{-3} \mathrm{~Pa}\right)$ and the composition of the residual gases with an acceptable content of hydrogen, nitrogen and other impurities.

3. It was found that the performance of the injector using a non-evaporated getter $\operatorname{Zr}(86)-\mathrm{Al}(14)$ is maintained for more than $500 \mathrm{~h}$, while saving energy consumption.

4. The analysis of all the results obtained in this study made it possible to better understand the processes occurring in the injector chamber of the linear accelerator of protons and thereby more thoughtfully 
and purposefully plan and carry out the necessary experiments on it.

\section{REFERENCES}

1. V.V. Koloskov et al. Linear proton accelerator I2. Vacuum system // Instruments and experimental techniques. 1967, N 5, p. 43.

2. N.I. Aizatsky, Yu.M. Arkatov, V.A. Bomko, et al. Academician Anton Karlovich Walter, Part II, NSC KIPT. Kharkov: Fort Publishing House, 2005, 235 p.

3. G.L. Saksaganskiy. VIII International Vacuum Congress // Express information of TsINTI and TEP on chemical and petroleum engineering. Series XM-6. 1986, N 4, p. 16.

4. V.M. Azhazha, P.N. Vyugov, I.E. Kopanets, et al. Accumulation and retention of hydrogen and deuterium in zirconium alloys and low-alloy steels with additions of getter alloys based on zirconium // Problems of Atomic Science and Technology. Series "Vacuum, Pure materials, Superconductors". 2006, N 1, p. 41-48.

5. Sorb AC Curtridge pumps: SAES-Getters advertising catalog. SAES Group www.saesgroup.com neg_technology@saes-group.com

6. V.S. Kogan, V.M. Shulaev. Adsorption-diffusion vacuum pumps with non-sprayable getter: Review. M.: "CRI of Atominform”, 1990, $67 \mathrm{p}$.

7. D.Zh. Yarwood. High vacuum technique // M.: "Gosenergoizdat", 1960, $313 \mathrm{p}$.

8. N.V. Cherepnin. Sorption phenomena in vacuum technology. M.: "Soviet. radio", 1973, 383 p.

9. P. Dore. Surface treatment and material degassing. Sorption processes in vacuum // M.: "Atomizdat", 1966, chapter 15, $313 \mathrm{p}$.

\title{
ПРИМЕНЕНИЕ В ЛИНЕЙНОМ УСКОРИТЕЛЕ ПРОТОНОВ НЕИСПАРЯЕМОГО ГЕТТЕРА Zr(86)-Аl(14), РАЗМЕЩЕННОГО ВНУТРИ КАМЕРЫ ПЛАЗМЕННО-ИОННОГО ИНЖЕКТОРА ПРОТОНОВ ДЛЯ ЕЕ ДОПОЛНИТЕЛЬНОЙ ОТКАЧКИ
}

\author{
А.Н. Аксенова, В.В. Беликов, С.А. Вдовин, П.Л. Махненко, Н.Н. Пилипенко, А.П. Подоляк, \\ Е.И. Пономарчук, А.П. Свинаренко, В.И. Скибин
}

\begin{abstract}
Проведены измерения скоростей откачки водорода и азота в камере плазменно-ионного инжектора протонов с размещенным внутри нее неиспаряемым геттером $\operatorname{Zr}(86)$ - $\mathrm{Al}(14)$. Измерения проведены в интервале температур 473...1300 К и давлений $13 \ldots \sim 10^{-3}$ Па. Установлены наибольшие скорости откачки водорода $((283 \pm 15)$ л/с) и азота $((133 \pm 15)$ л/с), достигаемые в интервале температур $525 \ldots 575$ К и давлений $13 . . \sim 10^{-3}$ Па. Показано, что предложенный неиспаряемый геттер $\operatorname{Zr}(86)-\operatorname{Al}(14)$ обеспечивает необходимое рабочее давление в камере плазменно-ионного инжектора линейного ускорителя протонов и минимальную концентрацию водорода, азота и других остаточных газов.
\end{abstract}

\section{ВИКОРИСТАННЯ В ЛІНІЙНОМУ ПРИСКОРЮВАЧІ ПРОТОНІВ ГЕТЕРА $\mathrm{Zr}(86)-A I(14)$, ЩО НЕ ВИПАРОВУСТЬСЯ, РОЗМШЩЕННОГО ВСЕРЕДИНІ КАМЕРИ ПЛАЗМОВО- ІОННОГО ІНЖЕКТОРА ПРОТОНІВ ДЛЯ Ї̈̈ ДОДАТКОВОГО ВІДКАЧУВАННЯ}

\author{
Г.М. Аксьонова, В.В. Бєліков, С.А. Вдовін, П.Л. Махненко, М.М. Пилипенко, А.П. Подоляк, \\ С.І. Пономарчук, О.П. Свинаренко, В.І. Скібін
}

\footnotetext{
Проведені виміри швидкостей відкачування водню і азоту в камері плазмово-іонного інжектора протонів 3 розташованим всередині неї для ії додаткового відкачування гетером $\operatorname{Zr}(86)-\mathrm{Al}(14)$, що не випаровується. Виміри проведені в інтервалі температур $473 \ldots 1300 \mathrm{~K}$ і тисків $13 \ldots \sim 10^{-3}$ Па. Установлені найбільші швидкості відкачування водню $((283 \pm 15)$ л/с) і азоту $((133 \pm 15)$ л/с), що досягаються в інтервалі температур $525 \ldots 595$ K і тисків 13.. 10 $0^{-3}$ Па. Показано, що запропонований гетер, що не випаровується, $\operatorname{Zr}(86)-\operatorname{Al}(14)$ забезпечує необхідний робочий тиск у камері плазмово-іонного інжектора лінійного прискорювача протонів та мінімальну концентрацію водню, азоту та інших залишкових газів.
} 